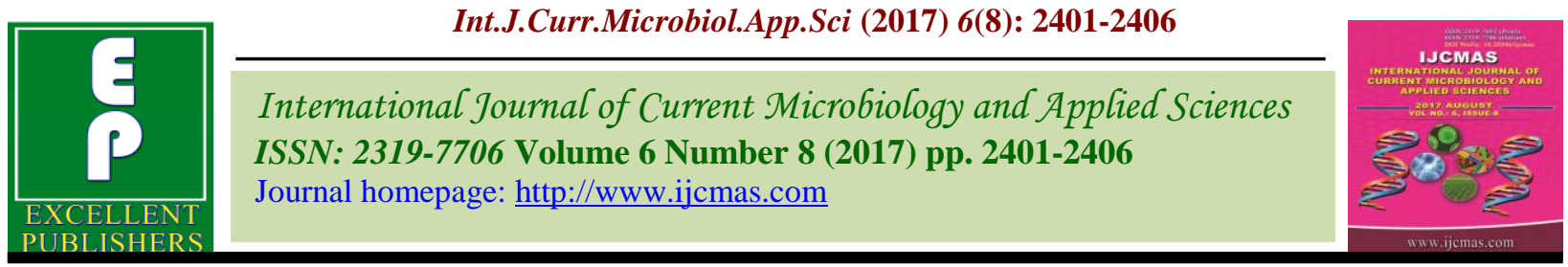

Original Research Article

https://doi.org/10.20546/ijcmas.2017.608.284

\title{
Assessment of Genetic Diversity for Brinjal in Terai Zone of West Bengal, India
}

\author{
Aparajita Das $^{1 *}$ and Soumitra Sankar Das ${ }^{2}$ \\ ${ }^{1}$ Department of Genetics and Plant Breeding, UBKV, Pundibari, \\ Cooch Behar, West Bengal-736165, India \\ ${ }^{2}$ Department of Agriculture Statistics, UBKV, Pundibari, Cooch Behar, West Bengal, India \\ *Corresponding author
}

\begin{tabular}{l} 
Ke y w o r d s \\
$\begin{array}{l}\text { Brinjal, Genetic } \\
\text { diversity, Cluster } \\
\text { analysis, } \\
\text { Hybridization. }\end{array}$ \\
\hline Article Info \\
\hline $\begin{array}{l}\text { Accepted: } \\
\text { 21 June } 2017 \\
\text { Available Online: } \\
\text { 10 August } 2017\end{array}$ \\
\hline
\end{tabular}

A B S T R A C T

For improving the yield potential of varieties and hybrids the decision should be made about the choice of right type of parents for hybridization. The present study was taken up at the Instructional Farm UBKV, Pundibari, Coochbehar, West Bengal during 2015-2016 for 8 characters of brinjal landraces. The 26 brinjal genotypes were grouped into eleven clusters based on $\mathrm{D}^{2}$ values. Cluster I and V were comprises maximum 4 genotypes. All other Cluster had digenotypic except Cluster XI was monogenotypic. The inter cluster distances were higher than the average intra cluster distances, which indicated wide genetic diversity among the genotypes of different groups than those of same cluster. On the basis of the cluster means the important cluster was cluster IV for fruit circumstances, average fruit weight, marketable yield plot $^{-1}$ and total yield plot $^{-1}$. The result of cluster mean clearly indicated that genotypes like UBB-8, Suphal-2 green (Malda) and Black Beauty could be selected as parents for future hybridization programme. The genotypes from the cluster I, IV and IV could be selected for hybridization programme to produce highly heterotic genotypes as these were found to be most divergent with a number of desirable traits.

\section{Introduction}

Brinjal (Solanum melongenum L.) is the most important vegetables crop of the world and a huge prospect in India. Brinjal, also known as eggplant or aubergine is one of the popular vegetable crops grown all over the country and throughout the year for its tender fruits. The name eggplant is derived from the shape of the fruit of some varieties, which are white in colour and similar in shape to chicken eggs. Several advanced cultivars and numerous landraces are cultivated in India for their young, unripe fruits, which are consumed fresh, dried or pickled (Karihaloo and
Gottileb, 1995). Eggplant fruit are a rich source of calcium, magnesium, potassium, iron, zinc and copper. It is also a fair source of fatty acids and may have medicinal properties (Shafeeq, 2005). White brinjal is said to be good for diabetic patients. It has also been recommended as an excellent remedy for those suffering from liver complaints (Shukla and Naik, 1993). A large indigenous biodiversity exists in eggplant with variation in plant type, stem color, leaf size, leaf tip, midrib color, fruit size, fruit shape, fruit color, fruit yield, fruit quality, 
cooking quality, and tolerance to pests and diseases (Ullah et al., 2014). Greater the variability in a population, greater is the chance for effective selection for desirable types (Vavilov, 1951). Further, the varietal preference for brinjal is strictly location specific and even within a location the acceptance differs from place to place. Hence, there is a need to develop varieties preferable and suitable to a particular location. Genetic architecture and the mode of inheritance of characters are important considerations to determine the breeding procedures. The existence of variability in a particular trait is an important prerequisite for its heritable improvement. For improving the yield potential of varieties and hybrids the decision should be made about the choice of right type of parents for hybridization. Therefore, induction of variability in brinjal is urgently needed for ultimate use in any crop improvement programme. It has been found that the progenies derived from crossing between divergent parents give divergent and useful trait. It has been often postulated by the breeders that geographical distribution reflects genetic diversity in selecting parents for hybridization. The importance of genetic diversity in the selection of suitable genotypes for hybridization has been stressed by several scientists in different crops (Kumar et al., 2003; Ivy et al., 2007; Mondal et al., 2007; Haydar et al., 2007). The qualification of genetic diversity has made it possible to choose genetically diverse parents for a successful hybridization program. Knowledge on genetic diversity, its nature and degree is useful for selecting desirable parents from a germplasm for the successful breeding programme. Multivariate analysis acts as a useful tool to quantify the degree of divergence between the biological populations at genotypic level and to assess the relative contribution of different components to the total divergence at both inter and intra cluster levels. D2 technique of
Mahalanobis appears to be a fruitful approach which is based on multivariate analysis and serves as a good index for estimating genetic diversity (Gadekar et al., 1992). The success of brinjal breeding programmes depends mainly on the identification of promising parental lines for making desired crosses and selection of superior genotypes from the progenies. Distantly related lines are assumed to be more complementary and produce superior heterotic progenies (Islam et al., 2011; Sandhu et al., 2001; Joseph et al., 1999). Hence, the present study was taken up with 26 brinjal genotypes from northern part of West Bengal to ascertain the nature and magnitude of genetic diversity present in the material which would ultimately help to identify parents for future breeding program.

\section{Materials and Methods}

The field experiment was conducted at the Instructional Farm UBKV, Pundibari, Coochbehar, West Bengal during winter (Rabi) season in 2015-2016. Twenty six brinjal genotypes namely UBB-7, Ashapuri Ghia (Malda), Chand Tara, Panjipara Local, Kabragol, UBB-6, Kokila, PPL, UBB-8, Suphal-2 green (Malda), Black Beauty, UBB5, Muktakeshi, Pasidewa Local-2, Dhapa black, Joshna (Malda), Long black(baromasi), Ashapuri Changa brinjal (Malda), Hajipur Bharta brinjal (Malda), Muktamala, Mukta Brinjal Green (Malda), Boldgaga sp. Mukta, Long and Thick, Long golden brinjal (Dinhata) were collected from different part of North Bengal. The experiment was laid following randomized block design with 3 replication. The unit plot size was $3 \mathrm{~m} \mathrm{X} 3 \mathrm{~m}$ with row to row spacing was $60 \mathrm{~cm}$. The intercultural operations were done timely to raise a good crop. Observations were recorded from 10 randomly selected plants in each line for days to first flowering, plant height $(\mathrm{cm})$, fruit length $(\mathrm{cm})$, fruit length $(\mathrm{cm})$, average fruit weight, unmarketable yield/plot $(\mathrm{kg})$, 
marketable yield/plot(kg), yield/plot $(\mathrm{kg})$. Genetic diversity was studied following generalized distance $\left(\mathrm{D}^{2}\right.$ statistic $)$ (Mahalanobis, 1936). Clustering of genotypes was done according to Tocher's method (Rao, 1952). All the statistical analysis was carried out using Genres computer software.

\section{Results and Discussion}

Multivariate analysis is used to study morphologically complex individual and for measuring the degree of divergence between biological populations (Prabakaran, 2010). Analysis of variance revealed that the differences in 26 brinjal genotypes were significant for all the characters indicating the presence of notable genetic variability among them. Considerable variation in eggplant germplasm has been reported in studies by Senapati et al., (2009), Shafeeq (2005) and Kushwa and Bandhyopadhya (2005).

The magnitude of all possible $\mathrm{D}^{2}$ values between any two genotypes ranged from 26.368 to 1891.77 indicating a high diversity in brinjal genotype used in the study. Cluster analysis is commonly used to study genetic diversity, and for forming core subsets for grouping accessions with similar characteristic into homogenous category. All 26 brinjal genotypes were grouped into eleven clusters (Table 1). Cluster I and V was comprises maximum 4 genotypes followed by Cluster IV (3 genotypes) and XI (monogenotype) and others Cluster had digenotypic from a different geographical location. Geographic diversity, though appear to be an important factor it that it is not the only factor determining genetic divergence. Genotypes belonging to cluster I and V could have greater genetic divergence and intermating between the genotypes belonging to them would give more transgressive segregates in advanced generations. This finding was in agreement with the findings of other researcher (Kumar et al., 2013, Kumar et al., 2016). The grouping pattern showed that exotic and Indian genotypes (Table 1) were grouped together in various clusters as reported earlier (Kumar et al., 2007) confirming thereby that morphological diversity is not related to geographical diversity.

The average Intra and inter cluster distances are presented in table 2. The inter cluster distances were higher than the average intra cluster distances, which indicated wide genetic diversity among the genotypes of different groups than those of same cluster. Inter cluster distance was always higher than intra cluster distance. Similar results were reported by Kumar et al., (2007), Dutta et al., (2009) and Islam et al., (2011) in brinjal. The highest inter cluster distance was observed between Cluster IX and Cluster X (1891.77) and followed by Cluster IV and Cluster IX (1820.57) and Cluster VII and Cluster XI (1549.53) and the lowest between Cluster II and Cluster VII (78.02). It was found that intra-cluster values varied from 26.368 to 558.49 (Table 2). The highest intra-cluster distance was observed for the Cluster $\mathrm{X}$ (558.49) followed by Cluster IX (390.58) and Cluster V (372.067) and minimum for the Cluster II (26.368). Intra-cluster distance was much lower than the inter cluster one, suggested heterogenous and homogenous nature between and within groups, respectively (Kumar et al., 2013; Mondal, 2010; Mahalanobis, 1936). The maximum intra-cluster distance was in Cluster $\mathrm{X}$ indicating Cluster $\mathrm{X}$ comprises of the most heterogeneous types followed by Cluster IX.

The clusters which were closer to each other may not yield transgressive segregants or high heterosis. Intercrossing among the genotype from different clusters may generate large variability and it is expected to introduce high yield and transgressive segregants for population improvement programs. 
Table.1 Grouping of twenty six genotypes of brinjal

(Solanum melongenum L.) in different clusters

\begin{tabular}{|c|l|c|l|}
\hline SI. No. & Cluster No. & Total No. of genotypes & Name of genotypes \\
\hline 1 & I & 4 & UBB-7, Ashapuri Ghia (Malda), Chand Tara, Panjipara Local, \\
\hline 2 & II & 2 & Kabragol, UBB-6 \\
\hline 3 & III & 2 & Kokila, PPL \\
\hline 4 & IV & 3 & UBB-8, Suphal-2 Green (Malda), Black Beauty \\
\hline 5 & V & 4 & UBB-5, Muktakeshi, Pasidewa Local-2, Dhapa black \\
\hline 6 & VI & 2 & Debjhuri Hajari, Special Makra \\
\hline 7 & VII & 2 & Joshna (Malda), Long black (baromasi) \\
\hline 8 & VIII & 2 & Ashapuri Changa brinjal (Malda), Hajipur Bharta brinjal (Malda) \\
\hline 9 & IX & 2 & Muktamala, Mukta Brinjal Green (Malda) \\
\hline 10 & X & 2 & Boldgaga sp. Mukta, Long and Thick \\
\hline 11 & XI & 1 & Long Golden brinjal (Dinhata) \\
\hline
\end{tabular}

Table.2 Inter and Intra cluster (Diagonal) distance

\begin{tabular}{|l|l|l|l|l|l|l|l|l|c|c|c|}
\hline \multicolumn{1}{|c|}{ Sl. No. } & $\begin{array}{l}\text { Cluster } \\
\text { I }\end{array}$ & $\begin{array}{l}\text { Cluster } \\
\text { II }\end{array}$ & $\begin{array}{l}\text { Cluster } \\
\text { III }\end{array}$ & $\begin{array}{l}\text { Cluster } \\
\text { IV }\end{array}$ & $\begin{array}{l}\text { Cluster } \\
\text { V }\end{array}$ & $\begin{array}{l}\text { Cluster } \\
\text { VI }\end{array}$ & $\begin{array}{l}\text { Cluster } \\
\text { VII }\end{array}$ & $\begin{array}{l}\text { Cluster } \\
\text { VIII }\end{array}$ & $\begin{array}{l}\text { Cluster } \\
\text { IX }\end{array}$ & $\begin{array}{l}\text { Cluster } \\
\text { X }\end{array}$ & $\begin{array}{l}\text { Cluster } \\
\text { XI }\end{array}$ \\
\hline Cluster I & $\mathbf{1 5 7 . 3 7}$ & 170.38 & 233.66 & 327.15 & 365.96 & 370.32 & 267.71 & 215.73 & 1405.63 & 305.22 & 910.12 \\
\hline Cluster II & & $\mathbf{2 6 . 3 6 8}$ & 208.45 & 303.78 & 191.37 & 502.90 & 78.02 & 120.07 & 1293.64 & 203.95 & 493.20 \\
\hline Cluster III & & & $\mathbf{2 6 . 8 6}$ & 449.74 & 285.76 & 174.89 & 348.03 & 127.18 & 766.31 & 494.62 & 498.85 \\
\hline Cluster IV & & & & $\mathbf{3 0 9 . 0 5}$ & 572.68 & 603.93 & 373.96 & 424.28 & 1820.57 & 436.93 & 1022.64 \\
\hline Cluster V & & & & & $\mathbf{3 7 2 . 6 7}$ & 643.13 & 279.89 & 203.46 & 1150.12 & 414.61 & 473.21 \\
\hline Cluster VI & & & & & & $\mathbf{4 3 . 6 7}$ & 640.77 & 410.02 & 806.83 & 845.40 & 969.07 \\
\hline Cluster VII & & & & & & & $\mathbf{1 0 7 . 1 8}$ & 263.96 & 1549.53 & 254.63 & 468.65 \\
\hline Cluster VIII & & & & & & & $\mathbf{1 2 6 . 1 2}$ & 897.39 & 351.30 & 509.43 \\
\hline Cluster IX & & & & & & & & & $\mathbf{3 9 0 . 5 8}$ & 1891.77 & 1020.40 \\
\hline Cluster X & & & & & & & & & & $\mathbf{5 5 8 . 4 9}$ & 881.79 \\
\hline Cluster XI & & & & & & & & & & & \\
\hline
\end{tabular}

Table.3 Cluster mean of individual character in Solanum melongena L.

\begin{tabular}{|l|c|c|c|c|c|c|c|c|}
\hline \multicolumn{1}{|c|}{ Cluster } & DTFF & PH & FL & FC & AFW & UYP & MYP & YP \\
\hline Cluster I & 94.833 & 73.805 & 7.475 & 22.361 & 0.189 & 0.640 & 0.538 & 1.178 \\
\hline Cluster II & 100.833 & 82.963 & 9.630 & 22.507 & 0.178 & 0.349 & 0.826 & 1.176 \\
\hline Cluster III & 99.000 & 80.560 & 6.922 & 13.820 & 0.149 & 0.345 & 0.365 & 0.710 \\
\hline Cluster IV & 93.778 & 78.128 & 8.344 & 22.551 & 0.198 & 0.421 & 2.394 & 2.815 \\
\hline Cluster V & 96.333 & 89.596 & 8.798 & 20.710 & 0.156 & 0.212 & 0.373 & 0.585 \\
\hline Cluster VI & 97.667 & 53.838 & 7.268 & 12.617 & 0.158 & 0.303 & 0.565 & 0.868 \\
\hline Cluster VII & 94.667 & 80.435 & 11.643 & 22.190 & 0.189 & 0.636 & 0.849 & 1.485 \\
\hline Cluster VIII & 95.833 & 85.937 & 7.277 & 21.490 & 0.151 & 0.291 & 0.651 & 0.942 \\
\hline Cluster IX & 94.833 & 67.022 & 6.758 & 13.537 & 0.064 & 0.250 & 0.397 & 0.647 \\
\hline Cluster X & 96.167 & 88.122 & 8.877 & 24.948 & 0.198 & 0.264 & 0.597 & 0.861 \\
\hline Cluster XI & 90.333 & 98.383 & 12.400 & 12.093 & 0.122 & 0.238 & 0.573 & 0.811 \\
\hline
\end{tabular}

DTFF = days to first flowering, $\mathrm{PH}=$ plant height $(\mathrm{cm}), \mathrm{FL}=$ fruit length $(\mathrm{cm}), \mathrm{FC}=$ fruit circumference $(\mathrm{cm}), \mathrm{AFW}=\mathrm{average}$ fruit weight, UYP = unmarketable yield/plot $(\mathrm{kg}), \mathrm{MYP}=$ marketable yield/plot $(\mathrm{kg}), \mathrm{YP}=$ yield/plot $(\mathrm{kg})$.

Table.4 Character contribution in Solanum melongenum L.

\begin{tabular}{|l|c|c|}
\hline CHARACTER CONTRIBUTION & NO. OF FIRST RANK & \% CONTRIBUTION \\
\hline Days to first flowering & 0 & 0.000 \\
\hline Plant height $(\mathrm{cm})$ & 29 & 8.923 \\
\hline Fruit length $(\mathrm{cm})$ & 51 & 15.692 \\
\hline Fruit circumference $(\mathrm{cm})$ & 23 & 7.076 \\
\hline Average fruit weight & 70 & 21.538 \\
\hline Unmarketable yield/plot $(\mathrm{kg})$ & 65 & 20.000 \\
\hline Marketable yield/plot $(\mathrm{kg})$ & 36 & 11.076 \\
\hline Yield/plot $(\mathrm{kg})$ & 51 & 15.692 \\
\hline TOTAL & 325 & 100 \\
\hline
\end{tabular}


Any success through hybridization followed by selection depends primarily on the selection of parents having high genetic variability for different characters. While choosing the line as parents for hybridization for heterosis breeding, the per se performance of genotypeps with higher $\mathrm{D}^{2}$ values should be taken into consideration in addition to maximum inter-cluster distance.

Inter-genotypic crosses between members of clusters I and IX would exhibit high heterosis and is likely to produce new recombinants with desired traits. More emphasis should be given to cluster II and V in selecting inbreds for crossing in eggplant hybridization.

There was a wide range of diversity among the germplasm for quantitative traits. On the Basis of the cluster means (Table 3), the important cluster were cluster IV for fruit circumference $(\mathrm{cm})$, average fruit weight, marketable yield plot $^{-1}(\mathrm{~kg})$, yield plot $^{-1}(\mathrm{~kg})$.

Cluster $X$ for fruit circumference $(\mathrm{cm})$, average fruit weight, unmarketable yield plot ${ }^{1}(\mathrm{~kg})$. Cluster XI for days to first flowering, plant height $(\mathrm{cm})$, fruit length $(\mathrm{cm})$. Similar reports of non-correspondence between genetic and geographic diversity was also found in brinjal (Kumar et al., 2016). Cluster $\mathrm{I}$ and $\mathrm{V}$ was the largest cluster having 4 genotypes from different geographical sources shows that genetic divergence has no relationship with geographical divergence.

Contributing of characters towards diversity of the genotypes is given in table 4. The characters such as average fruit weight $(21.53 \%)$ followed by unmarketable yield plot $^{-1}(20.00 \%)$, fruit length (cm) (15.69\%) fruit yield plot $^{-1}(15.69 \%)$ and marketable yield plot $^{-1}(11.07 \%)$ for cluster IV followed by were the contributed more towards genetic divergence suggesting thereby that diverse genotypes can be utilized for improvement of yield productivity. Fruit yield had played their role in genetic diversity and such results indicated that those five characters contributed maximum towards diversity (Kumar et al., 2013).

The greater diversity in the present materials is due to these seven characters which will offer a good scope for improvement of yield through rational selection of parent's genotypes for brinjal producing.

It could be concluded that cluster IV were high performance for average fruit weight, marketable yield plot $^{-1}$ and yield plot $^{-1}$ and the above result of cluster mean clearly indicated that genotypes like UBB-8, Suphal-2 Green (Malda), Black Beauty could be selected as parents for future hybridization programme.

The genotypes from the cluster I, IV, V and X could be selected for hybridization programme to produce highly heterotic genotypes as these were found to be most divergent with a number of desirable traits.

\section{References}

Gadekar, D.A., Dhonukshe, B.L. and Patil, F.B. 1992. Genetic divergence in tomato. Vegetable Science. 19 (1): 30-35.

Haydar, A., Ahmed, M.B., Hannan, M.M., Razvy, M.A., Mandal, M.A., Salahin, M., Karim, R., and Hossain, M. (2007). Analysis of Genetic Diversity in Some Potato Varieties Grown in Bangladesh. Middle-East Journal of Scientific Research, 2(3-4): 146-148.

Islam, M.A., Nasrin, A.I., Mian, M.A.K., Shahadat, M.K. and Shahjahan, M. 2011. Genetic diversity in exotic eggplant (Solanum melongena L.). Libyan Agriculture Research Center Journal Internation. 2(1):15-19.

Ivy, N.A., Uddin, M.S., Sultana, R., and Masud, M.M. (2007). Genetic divergence in maize (Zea mays L.). Bangladesh J. 
Breed. Genet, 20(1): 53-56.

Joseph, T.A., Birhman, R.K., Sood, S.K., and Gopal, J. (1999). Genetic divergence in new potato genotypes. J. Indian Potato Assoc, 26: 119-25.

Karihaloo, J.L., and Gottlieb, L.D. 1995. Allozyme variation in the eggplant, Solanum melongena L. (Solanaceae). Theory and Applied Genetics. 90: 578583.

Kumar, R., Gupta, S.S., Singh, N. and Chandra, A. 2000. Evaluation of eggplant (Solanum melongena L.) germplasm under subtropical condition. Capsicum and eggplant Newsletter. 19: 115-118.

Kumar, S. R., Arumugam, T., and Ulaganathan, V. (2016).Genetic diversity in eggplant germplasm by principal component analysis. SABRAO Journal of Breeding and Genetics, 48 (2): 162-171,

Kumar, S., Singh, A.K., Sharma, J.P. and Sharma, N. 2007. Genotype clustering in brinjal (Solanum melongena L.) using D2 statistic. Haryana Journal of Horticultural sciences. 68 (3): 95-96.

Kumar, S.R., Arumugam, T., and Anandakumar, C.R. 2013. Genetic diversity in eggplant (Solanum melongena L.). Plant Gene and Trait. 4 (2): 4-8.

Kushwah, S., and Bandhyopadhya, B.B. (2005). Variability and correlation studies in brinjal. Indian J. Hort. 62:210-212.

Mahalanobis, P.C. (1936). On the generalized distance in statistics. Proc. Nat. Sci. (India), 2: 49-55.

Mondal, M.A.A., Hossain, M.M., Rasul, M.G., and Uddin, M.S. (2007). Genetic diversity analysis in Potato (Solanum tuberosum L.). Bangladesh J. Bot, 36(2): 121-125.
Prabakaran, S. (2010). Evaluation of local types of brinjal. M.Sc. thesis, Department of Horticulture, Tamil Nadu Agricultural University, Coimbatore, India.

Rao, C.R. (1952). Advance statistical methods in biometrical research. John Wiley and Sons Inc., New York, USA. 390p.

Sandhu, S.K., Kang, G.S. and Gopal, J. (2001). Genetic divergence based on nonhierarchical Euclidian cluster analysis in potato genotypes. Indian J. Hort, 58: 36065.

Senapati, N., Mishra, H.N., Bhoi, M.K., Dash, S.K., and Prasad, G. (2007). Genetic variability and divergence studies in brinjal (Solanum melongena L.). Veg. Sci. 36(2):150-154.

Shafeeq, A. (2005). Heterosis and combining ability studies in brinjal (Solanum melongena L.). M.Sc Thesis, Department of Horticulture, University of Agricultural Sciences, Dharwad, India.

Shukla, V. and Naik, L.B. 1993. Agrotechniques of solanaceous vegetables, in 'Advances in Horticulture', Vol.5, Vegetable Crops, Part 1 (K. L. Chadha and G. Kalloo, eds.), Malhotra Pub. House, New Delhi. 365.

Ullah, S., Ijaz, U., Iqbal, S. T., Najeebullah, M., and Niaz, S. (2014). Association and genetic assessment in brinjal. European J. Biotech. Biosci. 2(5):41-45.

Vavilov, N.I. 1931. The role of central Asia in the origin of cultivated plants. Bulletin of Applied Botany-Genetics and Plant Breeding. 263-44.

Vavilov, N.I. 1951. Origin, variation, immunity and breeding of cultivated plants. Chronol. Bot. 13: 4-364.

\section{How to cite this article:}

Aparajita Das and Soumitra Sankar Das. 2017. Assessment of Genetic Diversity for Brinjal in Terai Zone of West Bengal. Int.J.Curr.Microbiol.App.Sci. 6(8): 2401-2406.

doi: https://doi.org/10.20546/ijcmas.2017.608.284 